\title{
INNOVATION FOR THE REFLECTIVE SOCIETY
}

\author{
RICCARDO POZZO \\ DOI: $10.22163 /$ fteval.2019.367
}

\section{ABSTRACT}

66 Cultural innovation" sounds like an oxymoron. It is not, though. It is something real that tops up social and technological innovation. How can we measure "cultural innovation"? The answer is, as a result of co-creation. Items of cultural innovation are: content providers such as museums, science centres and libraries, as well as processes triggered by issues such as cosmopolitanism, inclusiveness, mobility, migration, heritage and creativity. Valuating the impact is fundamental to improve societal acceptance of public investment in culture, because these measurements may provide a basis for aligning research and innovation with the values, needs and expectations of society. In recent years, it has become clear that co-creation plays a central role within open innovation, because a "specific innovation can no longer be seen as the result of predefined and isolated innovation activities but rather as the outcome of a complex co-creation process involving knowledge flows across the entire economic and social environment" (Open Science, Open Innovation, Open to the World. EC 2016, p. 11). The paper offers migration-relate case studies for evaluating the impact of cultural innovation in societies that aim at being innovative, reflective and inclusive.

\section{INTRODUCTION}

"Social and Cultural Innovation" is a syntagma that is receiving increased usage among researchers after it was chosen by the "European Strategy Forum Research Infrastructures" (2016) for the name of the working group that deals with research infrastructures primarily connected with Social Sciences and the Humanities (SSH). Innovation refers to the creation of new products and services by bringing a new idea to the market. Economic growth turns on infrastructures, which provide access to services and knowledge, e.g. by overcoming the digital divide. Globalisation has made it clear that a most urgent objective is to work out policies of social and cultural innovation to the advantage of citizens - policies that aim at achieving changes in the regulatory environment that make societies both inclusive and reflective. Thinking ahead of Horizon Europe, there is some fear the notion of "cultural innovation" might sound like an oxymoron, no doubt. It is not, though. Cultural innovation is something real that tops up social and technological innovation by providing the reflective society with spaces of exchange in which citizens engage in the process of sharing their experiences while appropriating common goods content. We are talking of public spaces such as universities, academies, libraries, museums, science-centres, but also of any place in which co-creation activities may occur, e.g., research infrastructures such as "DARIAH-Digital Research Infrastructure for the Arts and the Humanities". At this level, social innovation becomes reflective and generates cultural innovation.

\section{REFLECTIVE SOCIETY}

The "reflective society" is also a syntagma that has found wide usage among researchers since a precise date, in this case the fall of 2013, when the European Commission introduced it for posting Social Sciences and Humanities related calls within the sixth societal challenge of Horizon 2020, the one about "Inclusive, innovative and reflective societies". The last adjective refers to the role of deliberative communication of citizens in a modern public sphere aiming at mutual understanding and goes back to Immanuel Kant (1790), G.W.F. Hegel (1812-13), Jürgen Habermas (1973), James S. Fishkin (1993), Ulrich Beck, Anthony Giddens and Scott Lash (1996) as well as Alessandro Ferrara (1998). A closer scrutiny reveals that Habermas has applied to society what Hegel had elaborated as the passage from the surface of being to the ground of essence, a passage that takes place, literally, by reflecting into the thing - like reflected light that illuminates something previously invisible, or creates a pattern not previously existing. Insisting on reflexivity helps to raise awareness for the importance of framing issues around engaging with science and society, identifying problems and defining solutions. The "Faro Framework Convention on the Value of Cultural Heritage for Society" of UNESCO (2007) encourages reflection on the role of citizens in the process of defining, creating, and managing a cultural environment in which communities evolve.

It is true, innovation is part of economics, because it is about money generating knowledge. There is, however, innovation in society and in culture. Social and cultural innovation is a fact. While according to the traditional - so-called Mode 1 - knowledge production, which is motivated by scientific knowledge alone (fundamental research) and is neither bothered by the applicability of its findings nor by bridging over to other disciplines, in contemporary research, multidisciplinary teams so-called Mode 2 - are brought together for short periods of time to work on specific problems in the real world for knowledge production. This mode can be explained by the way research funds are distributed among scientists and how scientists focus on obtaining these funds (Gibbons, Limoges, Nowotny, Schwartzmann, Scott and Trow 1994). Relatively recent models, such as triple helix and open innovation have stressed that the collaboration among different institutions is crucial for successful innovation. But only marginally these models have taken into account the actual and potential role that citizens in the reflective society have in shaping the innovation process (Leydesdorff and Etzkowitz 1998; Etzkowitz and Leydesdorff 2000; Carayannis and Campbell 2009; Chesbrough 2003). 


\section{CULTURAL INNOVATION}

What is social innovation we know about: it ought to be the backbone of all European research policies, as Marcelo Rebelo de Sousa, President of the Republic of Portugal, made it clear in the concluding remarks he gave at the Opening up to an Era of Social Innovation Conference in Lisbon on 28 0ctober 2017. We still know little about cultural innovation, though. The syntagma is mentioned at times just to say that culture too needs innovation and in fact produces innovation: museum studies foster innovation in museography; archaeology fosters innovation in data science that becomes data humanities; music and art foster innovation through social networks. There are even studies in the "philosophy of museums", whose items are questions such as "What types of value do museums have? What is the ethically correct stance for a museum to take towards its public? And towards the objects constituting its collection? Should museum exhibits seek to make a claim to objectivity?" (Harrison, Bergqvist and Kemp 2016). In sum, we can talk of "heritage-led innovation", which means that culture fosters technological innovation. Digitisation is in itself innovation. Data science has become data humanities. We still need a great deal of reflection on digitisation. However, we can look at it the other way around. Cultural innovation tops up social innovation, which on its turn relies on technological innovation. Innovation must come to term with social innovation, then, this is a European requirement.

The question is what part of social innovation is cultural innovation and what rights can cultural innovation claim with respect to society (Koefoed 2017)? A preliminary answer is: European cultural heritage marks our cultural identity, which is at the same time cultural diversity. The "European Year of Cultural Heritage" is about identity and diversity, said Jean-Claude Juncker in his opening speech at the European 2017 Culture Forum in Milan on 7 December 2017. But to assess cultural innovation as the value-sensitive integration to technological and social innovation is the great challenge contemporary "Science and Technology Studies" are confronted with and we need to look at it more closely. The new "missions" of the next "European Framework Programme for Research and Innovation" of the multi-annual financial period 2021-2027 will foster research on systemic change in the new generations and contribute to the creation of a cross-border and multi-disciplinary open innovation environments for research data, knowledge and services with engaged stakeholders and organisations. The current migrant crisis has made it clear with extraordinary force that a most urgent objective is to work towards Euro-Mediterranean societies that are inclusive, reflective, and attentive to the impact that migration is having on social and cultural innovation, security and health, environment and biodiversity.

The biggest challenge of this century, which is migration, asks for a new narrative of inclusion and reflection. Kantian philosophy, e.g., has the best chances to provide it. What Kant has written on the right of visit (das Recht eines Fremdlings), on hospitality (hospes) and sovereignty (hostis) is the key to shaping the narrative. The commentary to the third definite article of Perpetual Peace makes it clear that "originally no one has more right [Recht] than another to live on a particular place [Ort] on the earth" (Kant 1795, p. 41). Looking at late eighteenth-century colonialism, Kant envisaged a form of ius cosmopoliticum (Weltbürgerrecht), whose consequence is universal hospitality (allgemeine Hospitalität), which is to be acknowledged as the right of the foreigner (das Recht eines Fremdlings), although hospitality does not entail the right of the foreigner to rob, exploit, and enslave (Kant 1797). In sum, philosophy, in its historical dimension, is able to grant a shared narrative of what has happened, what is happening and what will happen with migration in our globalised world. On the basis of a cross-disciplinary approach, philosophers is to be trusted to achieve what Hanna Arendt (1963) did achieve for the Holocaust and Jürgen Habermas (1991) for citizenship, by pushing forward the recent proposal of Donatella Di Cesare (2017) for a philosophical narrative of migration.

It is now time to examine the role of reflection for rethinking the ways in which culture has been envisioned, particularly to visualise the various ways in which users engage with cultural processes in the past, present, and future. Let me propose a case study. Imagine a second-generation diaspora child (huaqiao 华桥) who attends a human sciences high school in Italy. At a certain point, s/he might be asked to read a text by Plato, possibly the Apology of Socrates (Apologia Sokratous Aпо入оyía $\Sigma$ ¿шко́точ५), first in Italian, then perhaps in the Greek original or in the Renaissance Latin rendering of Marsilius Ficinus. Students today delve easily into multilayered, multilingual hypertexts, and they do so on the basis of the reciprocal guidance made possible by social reading tools. Our student ought to read the same text in modern unified Chinese as well, so that s/he might be able to start a discussion on Socrates in its Chinese-speaking family. Inversely, schoolmates might appropriate, say, the Analects (Lunyu 伦语) of Confucius through the conceptual references indicated by our student. Together they may start thinking on movement (dong 动), rest (jing 静), human being (renji 人际), humaneness (ren 仁), and eventually come to grasp key tenets of Neo-Confucianism, such as the dictum that represents the unity of heaven and human or supernal heaven and humanity (tianrenheyi 天人合一), which amounts to "restoring the Heavenly Principle and diminishing human desires" (Wang 2005, p-320; Ni Peimin 2017).

\section{CONCLUSION}

Rémi Brague (2004) has noted that the Arabic term for dictionary, سوماق (qāmūs), is a translation of the name of the Titan of Greek

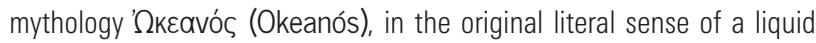
extension that embraces all emerged lands, permitting navigation and hence communication. Leibniz has used the ocean metaphor for an encyclopaedia, which is the very same idea concerning languages that this paper tries to defend. We expect SSH research to trigger a change in the mind-set as regards locating culture for inclusion and reflection in education, life-long learning, healthcare, urban development and regeneration. Culture cannot be but plural, changing, adaptable, constructed. Inclusion and reflection are constructed whenever we are in contact with other human beings, regardless where they come from. This we have to learn.

\section{REFERENCES}

Arendt, H. (1963). 'Eichmann in Jerusalem: A report on the banality of evil'. The New Yorker, 17 May and following

Beck, U., Giddens A. and Lash S. (1996). Reflexive Modernisierung. Frankfurt: Suhrkamp

Brague, R. (2004). 'Langues et traditions constitutives de la philosophie en Europe'. In: Cassin, B. (ed.) Vocabulaire européen des philosophies: Dictionnaire des intraduisibles, edited by, pp. 694-99, Paris: Seuil 
Carayannis, E. and Campbell, D. (2009). "'Mode 3" and "Ouadruple Helix": toward a 21 st century fractal innovation ecosystem', International Journal of Technology Management, 46, 201-34.

Chesbrough, H. W. (2003). Open innovation: The new imperative for creating and profiting from technology. Harvard University Press

DG-RqI (2016). Open science, open innovation, open to the world: A vision for Europe. Brussels: EC

Etzkowitz, E. and Leydesdorff, L. (2000). 'The dynamics of innovation: From national system and "Mode 2" to a triple helix of university-industry-government relations', Research Policy, 29, 109-23

Ferrara, A. (1998). Reflective authenticity. London: Routledge

Fishkin, J. S. (1993). The dialogue of justice: Towards a self-reflective society. Yale University Press

Gibbons, M., Limoges, C., Nowotny, H., Schwartzmann, S., Scott, P. and Trow, M. (1994). The New production of knowledge: The dynamics of science and research in contemporary societies. Thousand Oaks: Sage

Habermas, J. (1973). 'Wahrheitstheorien'. In: Fahrenbach H. (ed.) Wirklichkeit und Reflexion: Walter Schulz zum 60. Geburtstag, pp. 211-265. Pfüllingen: Neske

Habermas, J. (1991). Staatsbürgerschaft und nationale Identität. Frankfurt: Erker

Harrison, V. S., Bergqvist, A. and Kemp, G. (eds. 2016). Philosophy and museums: Essays on the philosophy of museums. Cambridge University Press

Hegel, G.W.F. (1812-13). Wissenschaft der Logik. Nürnberg: Schrag

Kant, I. (1790). Kritik der Urteilskraft. Königsberg: Nicolovius

Kant, I. (1795). Zum ewigen Frieden. Königsberg: Nicolovius

Kant, I. (1797). Metaphysik der Sitten. Königsberg: Nicolovius

Koefoed, 0. (2017). 'Cultural heritage and social innovation: A memory of the future?', Cartaditalia, 1: 417-44

Leydesdorff L. and Etzkowitz, E. (1998). 'The triple helix as a model for innovation studies'. In Science and Public Policy, 25, 3, 195-203 $\mathrm{NI}, \mathrm{P}$. (2018). Understanding the Analects of Confucius: A new translation of Lunyu with annotations, Albany, N.Y.: SUNY PreSS

Pozzo, R. and Virgili, V. (2016). 'Governing cultural diversity: Common goods, shared experiences, Spaces for Exchange', Economia della cultura, 26: 41-47, doi.org/10.1446/84035

Pozzo, R. and Virgili, V. (2017). 'Social and cultural innovation: Research infrastructures tackling migration', Diogenes: International Journal of Human Sciences, 64, doi.org/10.1177/0392192117739822
Wang, R. R. (2005). 'Zhou Dunyi's diagram of the supreme ultimate explained (Taijitu shuo): A construction of the Confucian metaphysics', Journal of the History of Ideas 66 (2005) \#3, pp. 307-323, doi.org/10.1353/ jhi.2005.0047

\section{AUTHOR}

\section{RICCARDO POZZO}

Department of Human Sciences, University of Verona Via San Francesco 22, Verona, 37129 (Italy)

E: riccardo.pozzo@univr.it 